\title{
Influence of Weathering on the Engineering Properties of Dacites in Northeastern Turkey
}

\author{
Fehmi Arikan' ${ }^{1}$ and Nihal Aydin ${ }^{2}$ \\ ${ }^{1}$ Jeoloji Etütleri Dairesi, Maden Tetkik ve Arama Genel Müdürlü̆̆ü, Eskişehir Yolu, Balgat, 06520 Ankara, Turkey \\ ${ }^{2}$ Maden Analizleri ve Teknoloji Dairesi, Maden Tetkik ve Arama Genel Müdürlüğ̈̈, Eskişehir Yolu, Balgat, 06520 Ankara, Turkey
}

Correspondence should be addressed to Fehmi Arikan, fehmi@mta.gov.tr

Received 14 February 2012; Accepted 29 March 2012

Academic Editors: D. Jacques, D. Mallants, and D. Zhou

Copyright ( 2012 F. Arikan and N. Aydin. This is an open access article distributed under the Creative Commons Attribution License, which permits unrestricted use, distribution, and reproduction in any medium, provided the original work is properly cited.

\begin{abstract}
The purpose of this study is to investigate dacites of different weathering grades from the Cakmakkaya and Damar open-pit copper mines in northeastern Turkey based on their mineralogical, petrographical, and geomechanical characteristics. The dacites for which surveys are carried out are mainly subjected to chemical weathering as well as physical disintegration and hydrothermal alteration. Discontinuities in this rock appear to be a major influence on the spatial distribution of weathering profiles, with the intensity of weathering increasing in the plagioclase phenocrystals and microlites as the weathering grade increases. The present results show that the type and amount of clay minerals increase as the weathering grade increases. As the weathering increases, the amount of mobile oxides, such as $\mathrm{Na}_{2} \mathrm{O}, \mathrm{MgO}$, and $\mathrm{CaO}$, decreases while $\mathrm{Fe}_{2} \mathrm{O}_{3}$ and the loss on ignition (LOI) content increase for most of the dacite samples. The microfracture frequency $\left(q_{\mathrm{mf}}\right)$ may be a good indicator of fabric changes, and methylene blue adsorption (MBA) test and LOI may be good indicators of chemical weathering for the dacites. Geomechanical laboratory tests indicate that the strength of the samples is controlled by weathering. Field observations and mineralogical analyses show that the effects of weathering are critical for slope stability.
\end{abstract}

\section{Introduction}

Weathering is an essential process that affects the mechanical properties of rock material and mass at shallow depths and on the surface through chemical and physical weathering. Physical weathering leads to the opening of discontinuities by rock fractures, progressively breaking down the original rock to a soil-like material representing advanced stages of weathering. Chemical weathering results in chemical changes in minerals and both physical and chemical weathering greatly affect the engineering structures found at or near the Earth's surface. The composition of sedimentary rocks is strongly influenced by the nature of weathering in the source area of the sediment. Chemical and physical weathering are also responsible for the formation of soils that supply nutrients to enable plant growth and control the Earth's surface morphology. Slope failures, erosion, and landslides often happen in areas that are strongly affected by weathering, and weathering is an environmental factor that impacts recent and/or historical sites. Weathering processes act as a buffer against a variety of environmental threats $[1,2]$ and also help to protect the environment $[3,4]$. Therefore, weathering is a very important process in the earth sciences.

Although the processes and outcomes of weathering have been investigated for many rock types, the review of literature shows that previous studies on rock weathering have generally focused on granitic and metamorphic rocks. Many researchers [5-10] have investigated variations in index properties during the weathering of granitic rocks, and similar observations on the weathering characteristics of metamorphic rocks have been made [11-13]. In addition, several researchers have explored the effects of weathering on sedimentary rocks [14-18]. Although some researchers [19-25] have focused on the influence of weathering on the engineering properties of volcanic rocks, only brief references have been made to the weathering characteristics of dacites. 
The lack of a systematic geotechnical study on this rock type stimulated the undertaking of the present research project.

For the current study, dacites of different weathering grades from the Cakmakkaya and Damar open-pit mines near Artvin in northeastern Turkey (Figure 1) were selected as the focus. In the field, the dacites were described in terms of their weathering grade based on visual descriptions and a number of simple index tests. Extensive surface and subsurface investigations were carried out to determine the characteristics and depth of weathering profiles developed in the rock. The field descriptions were verified by means of their mineralogical characteristics in the laboratory. We then determined the index and geomechanical parameters representing each weathering grade. The data obtained from the field and laboratory studies were statistically evaluated using simple regression analyses and best-fit curves were calculated. Color changes and slope failures in the dacites induced by weathering were investigated. Based on visual descriptions, the rock/soil ratio, Schmidt hammer rebound values, and RQD, a rock mass weathering classification system for the dacites was constructed.

\section{Geological Setting}

The eastern part of the Black Sea Region has long been known as one of the most landslide-prone areas in Turkey. Weathering processes, which affect rock masses, play a crucial role in the occurrence of landslides. Due to these processes, dacites covering large areas show a wide variety of slope movements in this region. The village of Damar, which is situated adjacent to the Damar open-pit mine, is located on an ancient landslide composed of soil-like material originating from the weathering of the dacites. This village is subjected to a very slow moving landslide, which causes destruction to agricultural lands and serious damage to buildings and structures.

The Cakmakkaya and Damar open-pit copper mines are located in the eastern part of the Black Sea Region of Turkey, approximately $55 \mathrm{~km}$ north of the city of Artvin (Figure 1). The region exhibits steep mountainous topographical features and receives heavy precipitation. The Cakmakkaya and Damar mines are two adjacent open pits separated by a sterile area where copper mineralization has not occurred. The investigated area corresponds to an island arc that was active from the Early Jurassic period through the Miocene period [26]. The succession consists of a thick volcanic series that is mainly represented by three volcanic cycles. The deposits around the mines are composed of volcano-clastic and volcanic rocks and are linked to the first volcanic cycle. The rocks in the study area, from bottom to top, are dacitic tuffs and breccias (main formation of the ore deposits), dacitic tuffs, purple tuffs, and dacites (Figure 2). The dacite pile that is a volcanic rock containing a mixture of plagioclase and other crystalline minerals in glassy slica is about $700 \mathrm{~m}$ thick and is purple in color. Although some researchers [27, 28 ] indicated that dacites have been affected by hydrothermal alteration in the proximity of the ore bodies, this study only includes the effects of weathering on the dacites and briefly discusses the hydrothermal alteration.

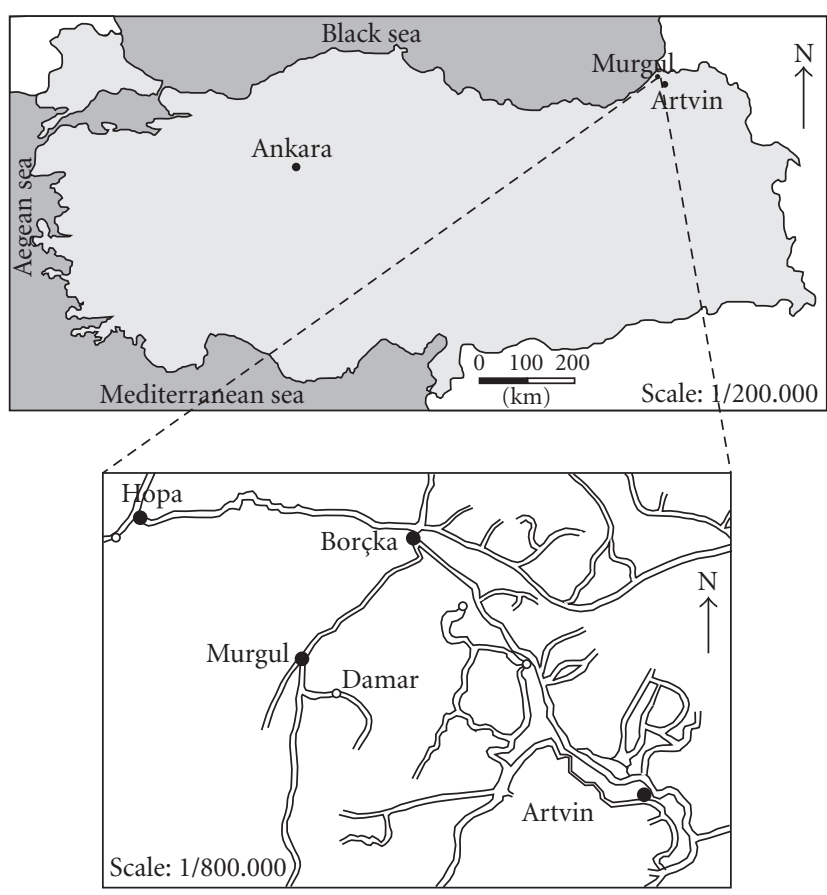

FIGURE 1: Location map of the study area.

\section{Field Study}

3.1. In Situ Description of Weathering. With regard to changes in the mechanical properties of the dacites, six grades of weathering on the material and mass scales have been distinguished in the field and are noted from Grades I to VI (I: fresh, II: slightly weathered, III: moderately weathered, IV: highly weathered, V: completely weathered, VI: residual soil). For the material scale, Grades I through IV represent rock properties, whereas the soil mechanic principals are represented by Grades V and VI. On the rock mass scale, Grades I and II are rocks, Grades III and IV are rock soil, and Grades V and VI are soil (Figure 2). The main engineering geological description in this distinction was based on the visual recognition of mineral alteration, rock and soil ratios, existence of original texture, joint staining, degree of discoloration, and a number of simple index tests suggested by ISRM [29].

\subsection{Lateral and Vertical Distribution of Weathering Profiles in} the Dacites. Line surveys and Schmidt hammer tests were performed on discontinuity surfaces in the dacites with different weathering grades to define the lateral variations due to weathering. Surveying was carried out along a $600 \mathrm{~m}$ line of the working benches of the dacites graded from I through IV [29]. The dacites in the study area contain two joint sets and other randomly orientated joints that display similar characteristics with little variations. The apertures of these discontinuity sets generally range between 2 and $6 \mathrm{~mm}$. The joints are classified as moderately to widely spaced and fall in the category of very high persistence joints ([29]; Figure 3(a)). The changes in joint properties induced by 


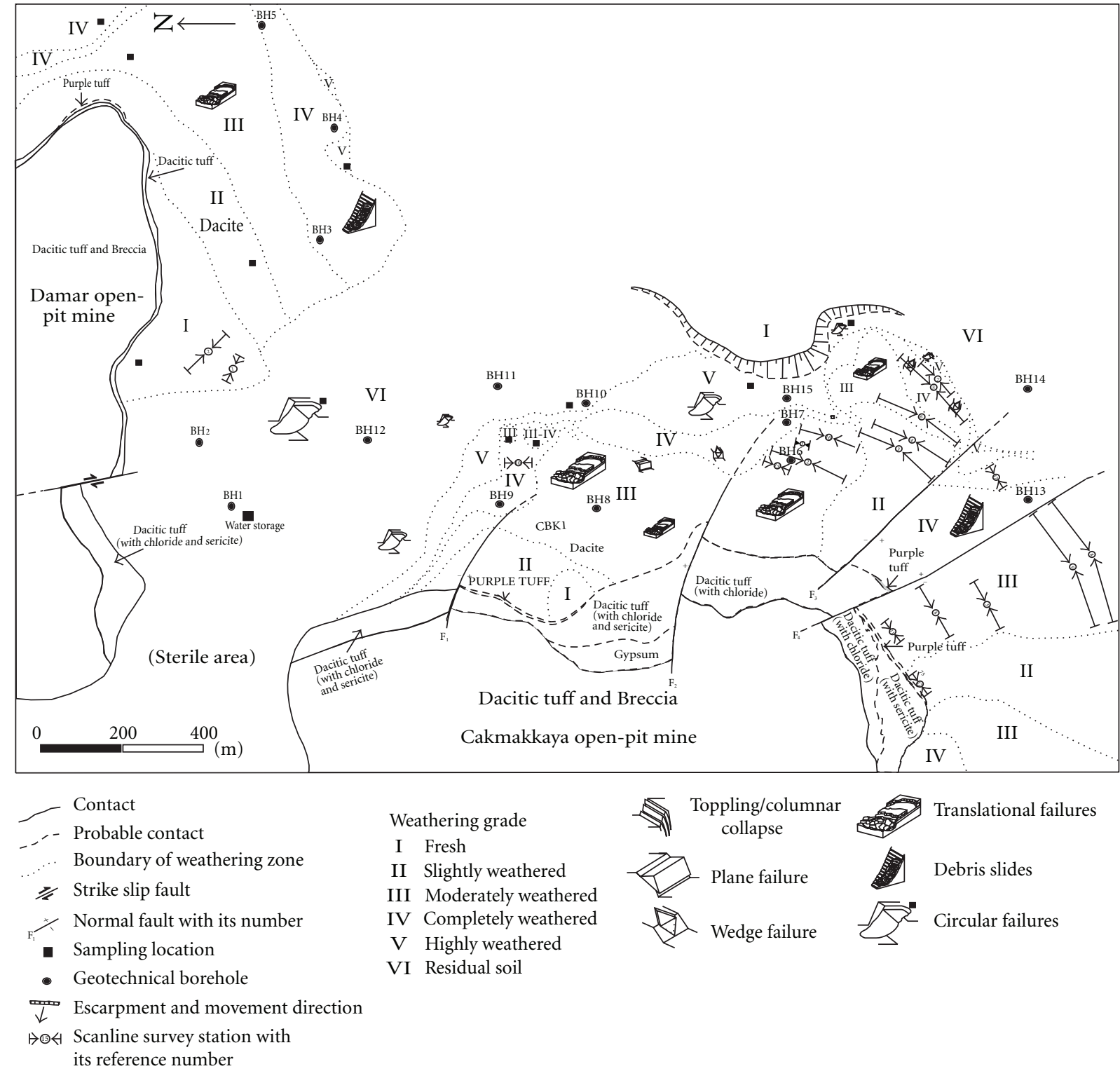

FIgURE 2: Typical weathering profiles developed in the dacites at the Cakmakkaya and Damar open-pit mines.

weathering in the dacites are mainly mineralogical. Discontinuity surfaces in Grade I rocks are fresh or slightly stained with hematite and/or limonite. The effects of oxidization are evident in Grade II rocks. In the moderately and highly weathered rocks, the joints are filled with clay in addition to the enrichment of iron. Relict joints and corestones are observed in Grade V (Figures 3(b) and 3(c)). In Grade VI, the original texture of the rock is lost and the rock has been converted to soil.

The effects of mechanical weathering in the dacites can be discerned through the degree of fracturing based on weathering grades. The results show that the mean fracture frequencies of the dacites increase with a rise in the weathering grade (Table 1), and this increase is particularly prominent between Grades II and III. Comparisons of the mean values demonstrate that the differences between Grades I and II and between Grades III and IV are very small.

Apart from the joint set, the rock mass is offset by several major faults that also serve as possible conduits for surface water circulation causing chemical weathering at the depth. Four sets of normal faults, labeled F1 to F4 (see Figure 2), are observed in the Cakmakkaya mine, while a strike-slip fault is evident in the Damar mine. The weak zones along the faults, which cause stability problems in the mines, represent advanced stages of weathering (Grades V and VI).

The other important physical process that contributes to the general weathering of the dacites in the mines is peeling. The stress release after removal of the overlying material 


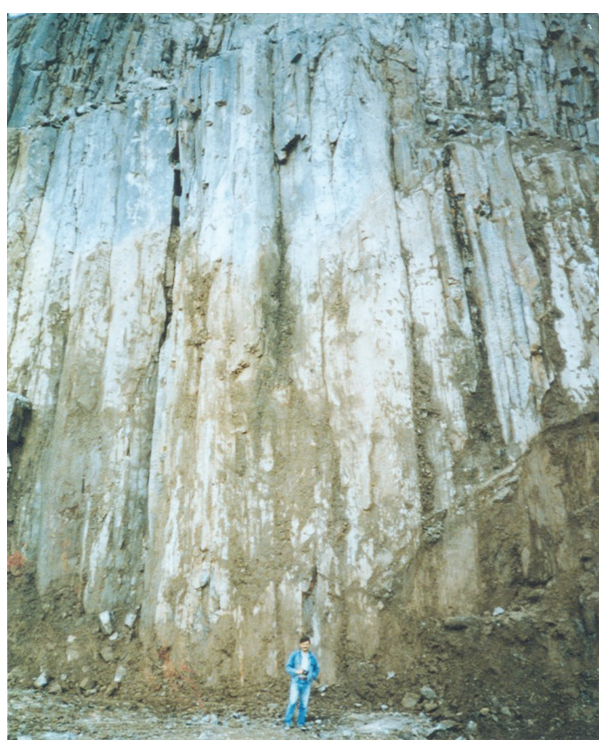

(a)

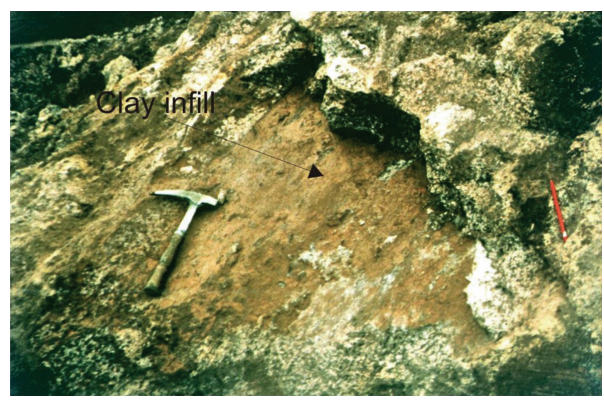

(b)

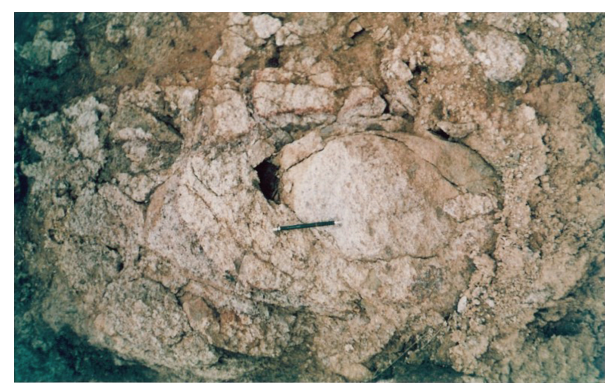

(c)

FIGURE 3: Relationship between Schmidt rebound values and weathering grades for the dacites.

and wetting-drying accelerate the rate of peeling in highly weathered dacites due to the smectite content that is defined by further mineralogical studies.

A total of 192 sets of Schmidt hammer tests were conducted on discontinuity surfaces in order to quantitatively characterize the weathering grades. Table 1 shows the ranges of Shv for different weathering grades for the dacites. In order to determine the relationship between Shv and weathering grades, the two parameters were correlated using simple regression analysis. The value of the correlation coefficients $(r)=0.80$ is considered significant at the $95 \%$ confidence level [30], so this value was thought to be the minimum value for acceptance of a possible relationship between the weathering grades and some properties of the specimens investigated in the present study. The relationship drawn between Shv and the weathering grades shows a strong correspondence between the two parameters $(r=0.94$; Figure 4). The results show that Shv decreases linearly with the weathering grade quantifying the extent of strength degradation along the discontinuity surfaces under the influence of weathering.

Indications related to the vertical sequence of different weathering grades were obtained from 15 boreholes drilled at the mines. About 2,100 $\mathrm{m}$ cores in different weathering grade areas were logged. The borehole logs show that the weathering profile displays an irregular pattern, and the weathering intensity generally decreases with increasing depth. Ranges of RQD values with respect to weathering grades for the dacites are given in Table 1. The statistical summaries of the RQD measurements show that the RQD values of the dacites decrease with increased weathering (Figure 5(a)). The maximum decrease in the values was observed from Grade II to Grade III. In addition, the lowest RQD value was obtained just below the ground surface, corresponding to highly weathered dacites. The borehole logs also show that the dacites are deeply weathered, down to $40 \mathrm{~m}$ in some places, and the weathering is particularly severe along the faults.

The hydraulic conductivity values $(K)$ of the weathered soil-like dacites at the top of the rocks in the study area, the weathered dacites from Grades I to IV beneath this material, and the dacitic tuffs underlying the dacite mass were between $4 \times 10^{-3}$ and $6 \times 10^{-4} \mathrm{~m} / \mathrm{s}, 4 \times 10^{-4}$ and $2 \times 10^{-5} \mathrm{~m} / \mathrm{s}$, and $3 \times 10^{-8} \mathrm{~m} / \mathrm{s}$ and $2 \times 10^{-8} \mathrm{~m} / \mathrm{s}$, respectively.

Discontinuities such as joints and faults having large hydraulic conductivity aid in the downward percolation of surface water so they cause chemical weathering at the depth similar to that at the surface. By considering the geological 
TABLE 1: Summary statistics for the discontinuity frequency and ranges of Schmidt rebound, and RQD (\%) values of the dacites in different weathering grades (NE: negative exponential).

\begin{tabular}{|c|c|c|c|c|c|c|c|}
\hline $\begin{array}{l}\text { Weathering } \\
\text { grade }\end{array}$ & $\begin{array}{c}\text { Number of } \\
\text { discontinuity }\end{array}$ & $\begin{array}{c}\text { Mean discontinuity } \\
\text { spacing }(\mathrm{m})\end{array}$ & $\begin{array}{l}\text { Discontinuity } \\
\text { frequency }(\mathrm{m})\end{array}$ & $\begin{array}{l}\text { Standard } \\
\text { deviation }\end{array}$ & Distribution & SHV & RQD (\%) \\
\hline I & 171 & 0.969 & 1.03 & 0.769 & $\mathrm{NE}$ & $54<\mathrm{SHV} \leq 62$ & $50-100$ \\
\hline II & 169 & 0.826 & 1.21 & 0.853 & $\mathrm{NE}$ & $40<\mathrm{SHV} \leq 53$ & $50-100$ \\
\hline III & 179 & 0.508 & 1.97 & 0.388 & $\mathrm{NE}$ & $30<\mathrm{SHV} \leq 39$ & $0-50$ \\
\hline IV & 231 & 0.405 & 2.47 & 0.312 & $\mathrm{NE}$ & $19<\mathrm{SHV} \leq 29$ & $0-50$ \\
\hline
\end{tabular}

Level of significance for means of discontinuity spacing: $95 \%$.

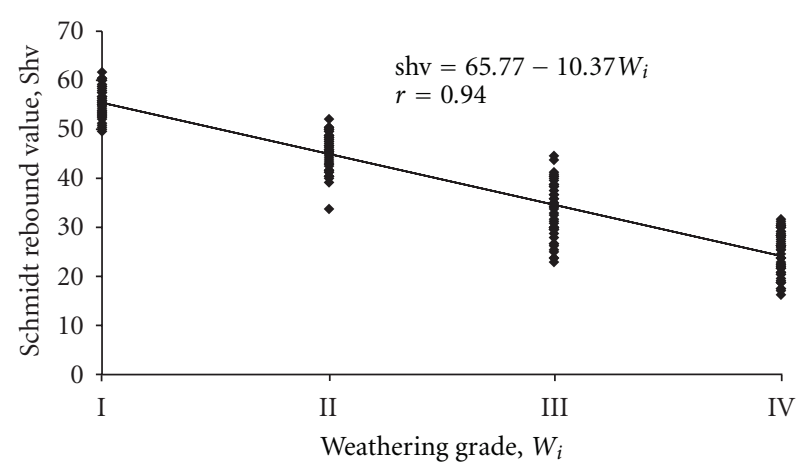

Figure 4: High persistent joints (a), relict structure as a discontinuity surface (b), typical corestones in the dacites (c).

sequence of the rocks in the study area from top to bottom, the hydraulic test results suggest that surface water percolates easily downward through pores, fissures, joints, and faults in the dacites, accumulating above the impermeable contact between the dacitic tuffs and dacites. The accumulated water above this contact contributes markedly to the chemical weathering of the bottom part of the dacites. Figure 5(b) is a photograph of drilling cores taken from the contact at a depth of $82.95-96.50 \mathrm{~m}$. This photograph clearly shows the advanced stages of chemical weathering of the dacites at a thickness of a few meters below the surface. Due to the presence of these discontinuities with large hydraulic conductivity, the weathering depth of the dacites in the study area is very nonuniform. On the other hand, the presence of minerals that are the byproducts of hydrothermal alteration, such as epidote, feldspar, and biotite, observed during the petrographic studies in most of the samples taken from the depth of the dacite mass to the surface indicates that the discontinuities provide hydrothermal alteration from the depth to the surface in the study area.

\section{Engineering Geological Properties of the Weathered Dacites}

The effects of weathering on the engineering geological properties of the dacite samples representing different weathering grades were examined in the laboratory. Sampling was carried out to recover both block samples from cut slopes and core samples from drill holes. Petrographical variations occurring in the samples were evaluated with the aid of a polarizing optical microscope. Mineralogical and major element analyses were undertaken using the $\mathrm{X}$-ray diffraction (XRD) technique, MBA test, and X-ray fluorescence (XRF). The physical and mechanical properties of the samples displaying rock properties from Grades I to IV were determined through a variety of laboratory tests, including unit weight and porosity determinations, the Schmidt hammer, uniaxial compressive strength (UCS), tensile strength (TS), block punch strength index (BPI) tests, and P-wave velocity measurements [29]. Porosity determinations were carried out using Beckman model pycnometers. Simple regression analyses were performed to investigate the relationships between these parameters and the weathering grade. Moreover, grain size distribution analyses were carried out to determine the properties of soillike material in Grades V and VI [31]. Color changes due to weathering were investigated.

4.1. Petrographical Properties and Characterization of the Weathered Dacites. For the petrographical analyses, 115 thin sections were prepared from the dacites in Grades I to IV with rock material properties. Mineralogical and fabric changes associated with the various weathering grades were determined through microscopic modal analysis. Thin sections of friable soil samples in Grades V and VI could not be prepared for analysis.

Groundmass is always at a higher ratio than the sum of the phenocrystals. The ratio of the ground mass varies between 55 and $60 \%$ at the minimum and 75 and $80 \%$ at the maximum, whereas the sum of the phenocrystals varies between 40 and 55\% at the maximum and 10 and $15 \%$ at the minimum. It is shown that the glassy material is present in the groundmass at a ratio of a minimum of $1-25 \%$ and maximum of $55-70 \%$. Moreover, the presence of plagioclase microlites in the groundmass is shown to be at a minimum of $0.5 \%$ and maximum of $5-35 \%$. The ratios for the opaque minerals are $0.5-5 \%$ (seldom $8 \%$ ) and the ratios for accessory minerals are less than $1 \%$. The quartz and plagioclase in the groundmass are the result of devitrification and are all primaries. The minerals formed by the weathering of glassy material are observed within the fabric of the quartz in the groundmass. All of the quartz particles are xenomorphic shaped and of equal length. Their grain size varies between 0.005 and $0.03 \mathrm{~mm}$. The plagioclase microlites are hypidiomorphic and bar shaped, with grain 


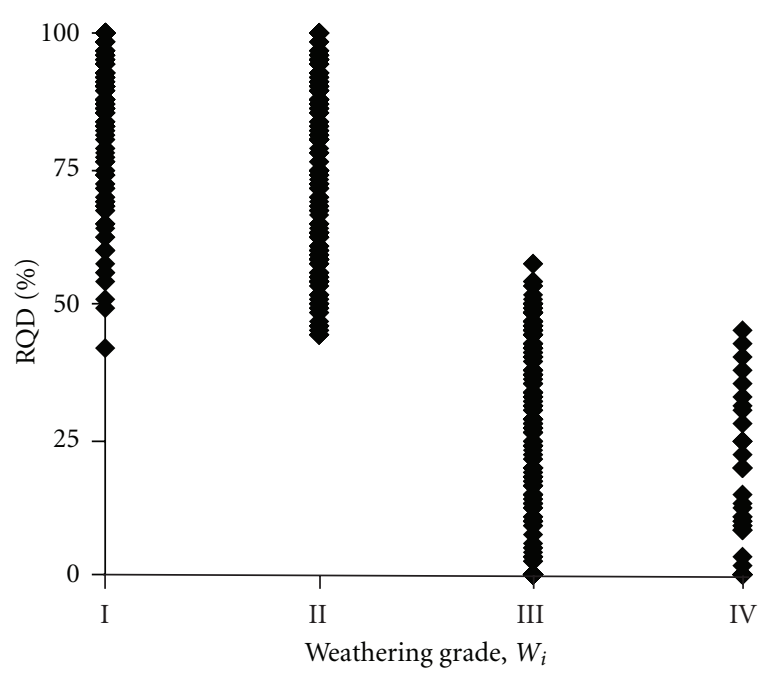

(a)

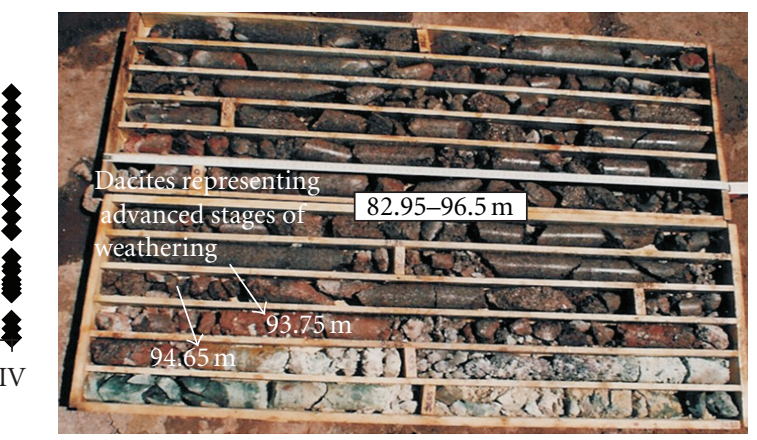

(b)

FIGURE 5: RQD versus weathering grade in the dacites (a), borehole cores showing weathering of the dacites below the surface (b).

size varying between 0.09 and $0.104 \mathrm{~mm}$. Mafic minerals are also hypidiomorphic and bar shaped. They are of equal length and have an average grain size of $0.8 \mathrm{~mm}$. Opaque minerals are generally magnetites and seldom pyridine, pyrite, or limonite. Apatite, epidote, and zircon are observed as accessory minerals.

Plagioclase phenocrystals are always more than quartz and mafic phenocrystals. They are about $10-15 \%$ at the minimum and $30 \%$ at the maximum. Most are oligoclase, with some being in andesine form. They are hyphidiomorphic and plate shaped and are occasionally found by themselves but are usually in groups. The fabric was observed as straight, straight curved, or curved at the triple points. These fabric properties are protected in the samples representing different weathering grades. Generally, crypto crystalline opaque inclusions are observed inside them, with altered glassy material inclusions rarely observed. Their average grain size is between 0.5 and $1.5 \mathrm{~mm}$. Quartz phenocrystals are present at a ratio of $7-20 \%$ when observed. They are xenomorphic and have been subjected to magnetic corrosion. Altered glassy material inclusions are commonly observed in quartz phenocrystals. Their average grain size is about $1.17 \mathrm{~mm}$. The phenocrystals of mafic minerals exist between 3 and $8 \%$ in the sample materials. Pyroxenes are hyphidiomorphic and plate-shaped. The grain sizes of the pyroxene phenocrystals vary between 0.6 and $1.7 \mathrm{~mm}$.

In the samples, epidote, feldspar, and biotite formed due to hydrothermal activity. On the other hand, sericite, clay minerals, hematite, and occasionally calcite were produced from chemical weathering. The glassy material and mafic minerals were affected by both of these processes. Opaque minerals were not found in abundance in the samples, but the intensity increased from Grade I toward Grade IV with an increase in the magnetite transformation into hematite. The by-products of the plagioclase phenocrystals were epidote after hydrothermal alteration and sericite after weathering. As the weathering increased from Grade II to III, epidote was observed at almost the same ratio but the amount of sericite increased (Figures 6(a), 6(b), and 6(c)). In Grade $\mathrm{IV}$, while no epidote was found, clay and carbonate were observed (Figure 6(d)). The amount of plagioclase microlites lessened and sericite content increased with the increase in weathering (Figure 7). The intensity of weathering increased in the plagioclase phenocrystals and microlites from Grade I to IV (Table 2). The weathering grades described in the field are generally in agreement with those found in the thin section assessments.

The $q_{\mathrm{mf}}$ was determined to characterize the extent of weathering in the dacites using the petrographical method suggested by Davis (1984) [32]. It can be expressed as

$$
q_{\mathrm{mf}}=\frac{L}{A},
$$

where $L$ and $A$ are the total length of the microfractures $(\mathrm{mm})$ and the unit area $\left(1 \mathrm{~mm}^{2}\right)$, respectively.

The results show a significant difference in $q_{\mathrm{mf}}$ between Grades II and III (Figure 8). Although the $q_{\mathrm{mf}}$ of the samples from Grades I and II were very close to each other, a notable difference was observed between Grades III and IV. There was also strong agreement between $q_{\mathrm{mf}}$ and the weathering grade $(r=0.91)$, with $q_{\mathrm{mf}}$ linearly increasing as the weathering grade increased. In other words, an increase in $q_{\mathrm{mf}}$ results in an increase in the surface area of the rock and the percolation of water becomes easier. All of these results are in full agreement with the frequency of fractures obtained from the line surveys.

4.2. Mineralogical and Chemical Properties. XRD analyses were performed on 30 dacite samples from Grades I to VI to support the petrographic observations for a complete mineralogical description. The results show that plagioclase and quartz are generally the main constituents of dacite. The dacite samples from Grade I do not contain clay minerals other than illite and chlorite formed by hydrothermal 


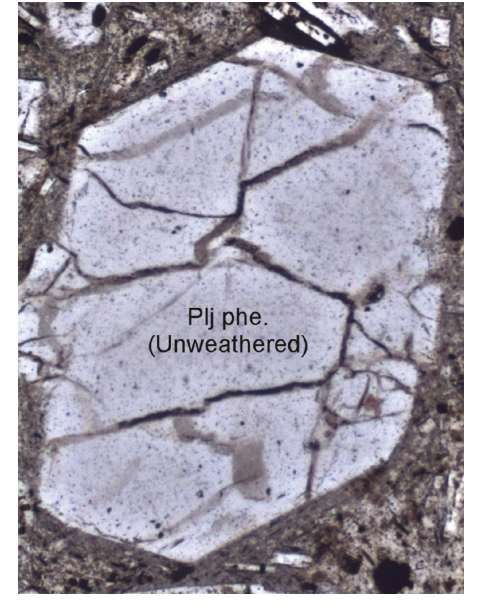

(a)

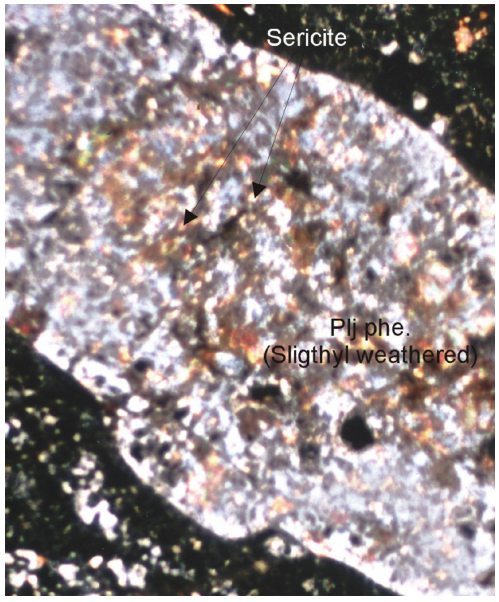

(b)

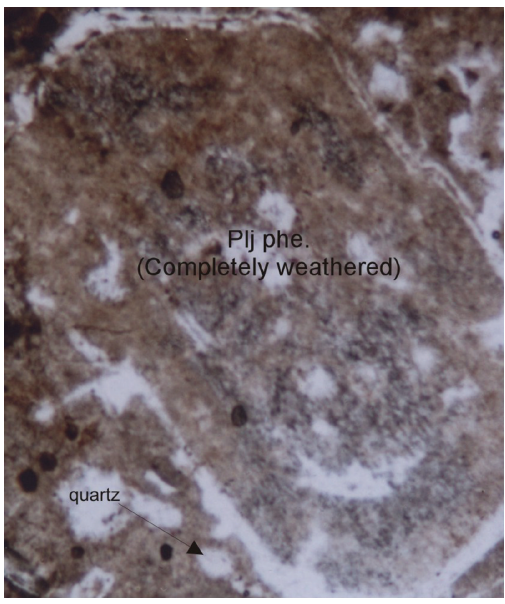

(d)

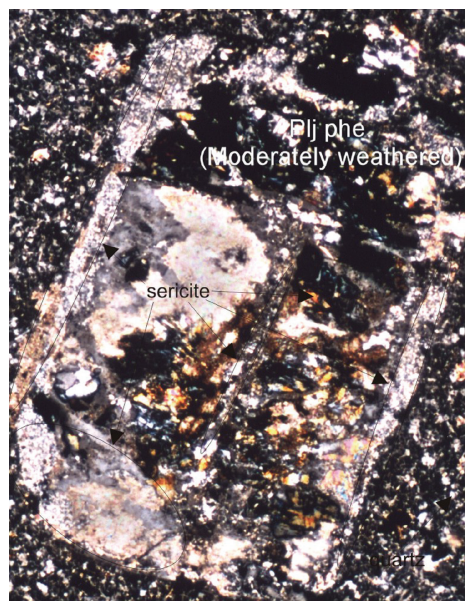

(c)

Figure 6: Photomicrographs showing plagioclase phenocrystals in the dacites representing each weathering grade from I to IV ((a)(d)) (crosed nicols, $\times 40$; Plj phe.: plagioclase phenocrystal). Fresh dacite with an unweathered plagioclase phenocrystal showing cooling microfractures and opaque inclusions, and with unstained plagioclase microlites in abundance (a), slightly weathered dacite with a slightly sericitized plagioclase phenocrystal and lesser amount of plagioclase microlites (b), moderately weathered dacite with a plagioclase phenocrystal showing an increasing amount of sericite around the edges and center (c), and highly weathered dacite with a plagioclase phenocrystal extensively weathered to clay minerals (d).

TABLE 2: Intensity of plagioclase microlites in groundmass and phenocrystals with respect to weathering grade.

\begin{tabular}{lcc}
\hline $\begin{array}{l}\text { Weathering } \\
\text { Grade }\end{array}$ & Plagioclase microlites & Plagioclase phenocrystals \\
\hline I & $85-100$ & $70-100$ \\
II & $45-85$ & $30-70$ \\
III & $25-45$ & $15-30$ \\
IV & $0-25$ & 0 \\
\hline
\end{tabular}

alteration [27]. A small quantity of mixed-layer clay minerals are developed as secondary products of primary minerals in the dacites during the early stages of the weathering process (Grade II). Kaolinite and hematite were identified as secondary minerals in the moderately weathered samples (Grade III). Smectite, which is present in the highly weathered samples, may be formed from the hydrolysis of glassy material, which is the main component of the ground mass of the dacites. Although the percentage of smectite is small $(<10 \%)$, it has a high shrink/swell potential and accelerates the breakdown of the dacites. The breakdown takes the form of cracking and scaling, leading to the formation of gravel and sand-sized particles. As the weathering continues, samples from Grades V and VI contain vermiculite, which are the weathering products of biotite and chlorite. Clay minerals occurring in the advanced stages of weathering of the dacites show that these clay minerals may have been formed in poorly draining environments. The analyses also showed that the majority of the clay minerals in the infill materials taken from the discontinuity, the relict joint, and 


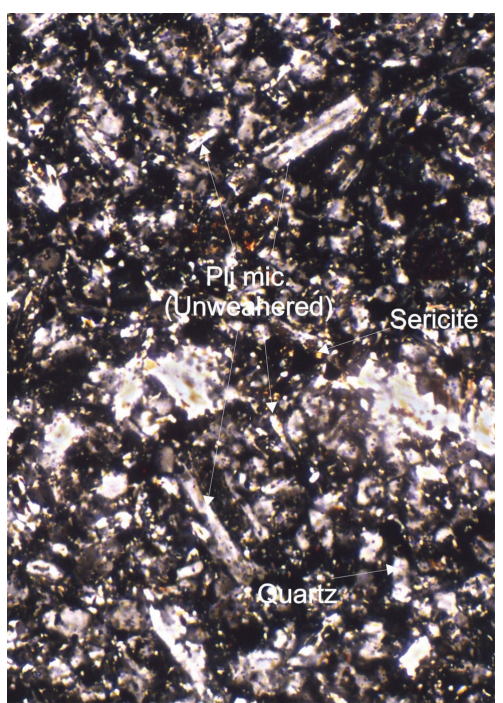

(a)

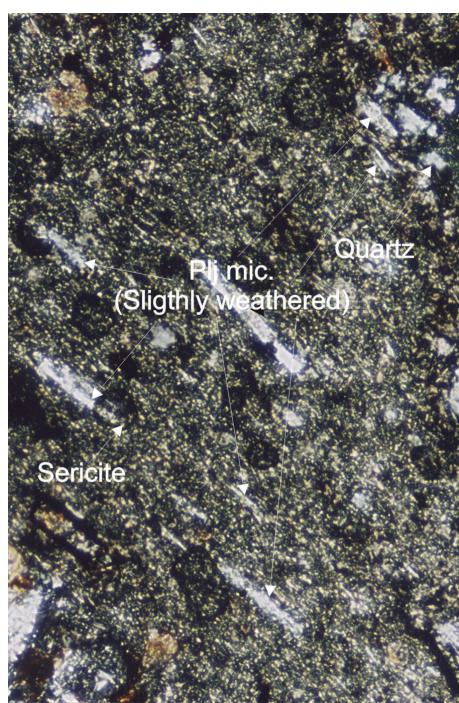

(b)

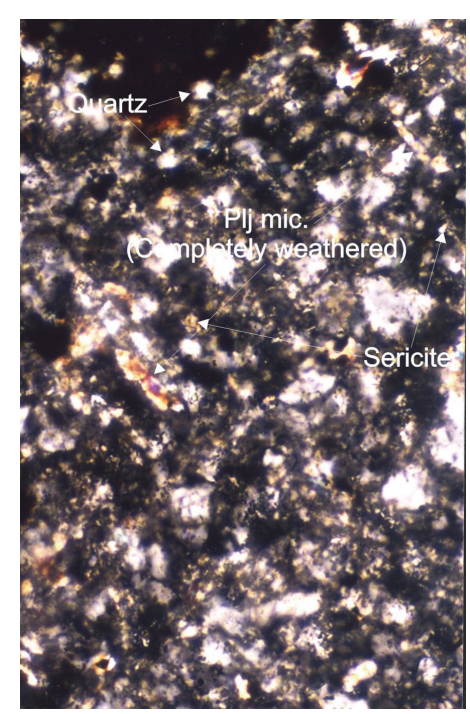

(d)

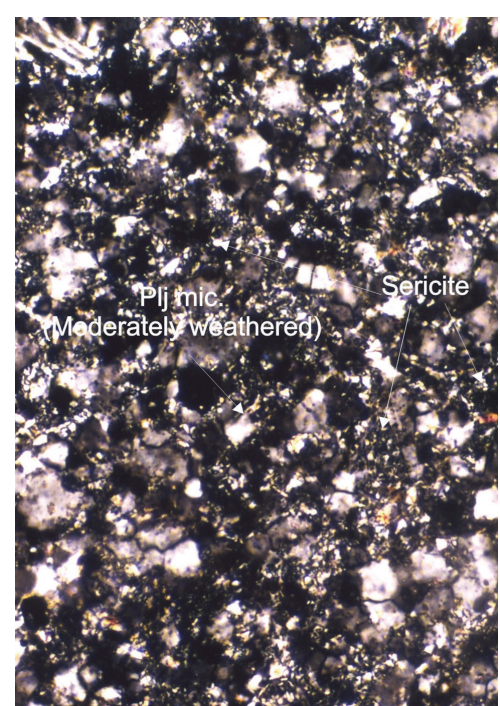

(c)

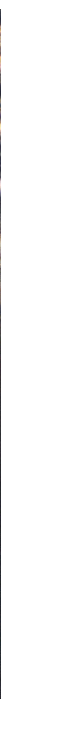

FIGURE 7: Photomicrographs showing the decreasing amount of plagioclase microlites and increasing amount of sericite content from Grades I to IV (crossed nicols, $\times 100((\mathrm{a}),(\mathrm{b})), \times 200((\mathrm{c})$, (d)); (Plj mic.: plagioclase microlite)). Fresh dacite consisting of a great amount of unweathered plagioclase microlites and trace amount of sericite (a), slightly weathered dacite showing a reduction in the amount of microlites and increase in the amount of slightly weathered sericite (b), moderately weathered dacite showing almost sericitized microlites (c), highly weathered dacite with completely sericitized microlites and replacement of these grains into groundmass $(\mathrm{d})$.

the failure surfaces in the weathered dacites from Grades III and IV, Grade V, and Grades II to VI, respectively, were kaolinite and smectite, both of which reduce shear strength.

The MBA test, which quickly indicates the presence of swelling clay minerals brought about by chemical weathering, was performed on a total of 40 samples [33]. Figure 9 shows the increase in cation exchange capacity (CEC) values with the change from fresh residual soil, with a correlation coefficient of 0.85 . This test giving good correlation $(r>$ 0.80 ) is suggested for the quantification of the weathering of the dacites. It is important to note that the dacites exhibited higher CEC values on account of their higher clay content with continued weathering and reached Grade VI as determined by X-ray diffraction.

A total of 33 samples from Grades I to VI were analyzed through XRF to validate the results of the mineralogical analyses. As illustrated in Table 3, the behaviors of the major elements do not display regular patterns with increased weathering intensity. The results of the chemical analyses show a general downward trend of $\mathrm{Na}_{2} \mathrm{O}, \mathrm{MgO}, \mathrm{K}_{2} \mathrm{O}$, and $\mathrm{CaO}$ and an upward trend of $\mathrm{Fe}_{2} \mathrm{O}_{3}$ with some exceptions, as weathering increases. The decomposition of feldspar results in a loss of $\mathrm{Na}_{2} \mathrm{O}$ and $\mathrm{CaO}$. Substantial reductions in $\mathrm{K}_{2} \mathrm{O}$ and $\mathrm{MgO}$ indicate that the majority of illite and chlorite 


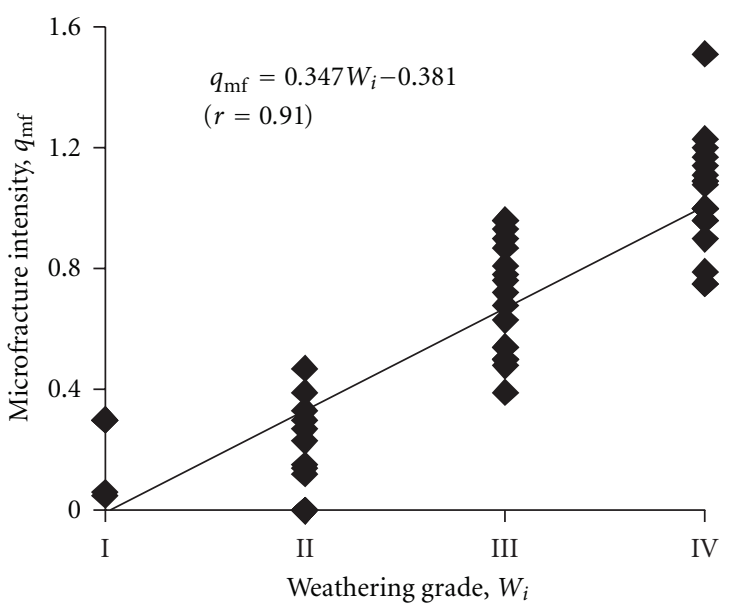

Figure 8: Microfracture intensities $\left(q_{\mathrm{mf}}\right)$ with respect to the weathering grades of the dacites.

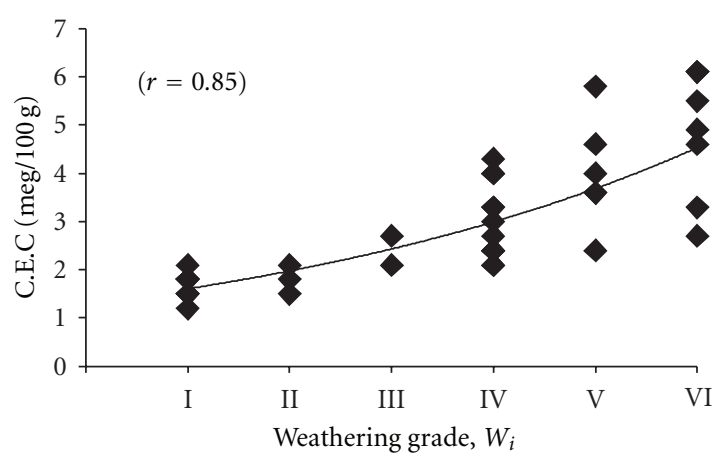

Figure 9: C.E.C. versus weathering grade for the dacites.

transform to kaolinite. The increase in the amount of $\mathrm{Fe}_{2} \mathrm{O}_{3}$ with an increase in weathering indicates that oxidation is a contributing weathering process for iron-containing minerals. The LOI content was found to increase regularly with weathering, suggesting the presence of secondary products such as clay minerals.

4.3. Effects of Weathering on Physical and Mechanical Properties of the Dacites. In order to determine the physical and mechanical properties of the dacite samples representing each of the weathering grades, geomechanical laboratory tests were carried out, and the test results are presented in Table 4. Figure 10 indicates that significant relationships were obtained between all of the index and mechanical properties of the dacites with the weathering grades. The figure shows that, as the weathering grade increases, porosity increases while the other parameters decrease, indicating that weathering weakens the strength of the samples. These findings are in agreement with those of previous studies on different rock types by Baynes et al., 1978 [34]; Dearman et al., 1978 [35]; Pasamehmetoglu et al., 1981 [36]; [19]; Beavis et al., 1982 [37]; [7, 11, 21]; Marques and Vargas 1998 [38]; Bell and Jermy, 2000 [39]; Thuro and Scholz, 2003 [40]; and Akin, 2010 [41].
Changes in the grain size for the weathered material behaving like soil from Grades V and VI were determined using a sieve and hydrometer analysis. The results of the grain size analyses indicate that sand- and gravel-sized fractions were abundant in the samples representing Grade V, while clay, silt, and sand-sized material were abundant in the samples representing Grade VI.

4.4. Change in Rock Color. Rock color reflects weathering and is the most visible index. In order to measure the color changes that occur due to weathering, we photographed the smooth surfaces of the rock samples obtained by cutting dacite blocks weathered from Grades I to IV and the soil samples from Grades V and VI (Figure 11(a)). These pictures were shot under natural lightning at a $90^{\circ}$ angle with a rather small aperture opening.

The average values of the distribution of the pixel reflection values were used. The pictures of the samples from different weathering grades were shot using the method described before, scanned on a scanner with $600 \mathrm{dpi}$ resolution, and transformed into gray-based digital data with reflection values varying between 0 and 256. In other words, the photographs were standardized by forming $200 \times$ 200 pixel digital data files. Histograms of the pixel reflection values of these digital images were drawn and their mean values calculated. Thus, the diagram in Figure 11(b) relates the mean value for each of the samples with the weathering grade of the individual sample. As shown in this diagram, the mean reflection values of the samples increase and hence the gray-toned colors become lighter as the weathering of the dacite samples increases. As a result of X-ray diffraction analyses realized within the scope of this work, clay minerals such as mixed-layered clay minerals, kaolin, and vermiculite are observed in relation with the increase in the grade of weathering. When all of these data are taken into account, it appears that the newly formed clay minerals play an important role in lightening the color of the samples lighter as the weathering grade increases.

\section{Distribution of Weathering-Related Failures in the Dacites}

In the study area, different types of slope instability are present [42]. An engineering geological documentation map for the study area shows that failures of the slopes may be strongly controlled by the distributed strength reduction within the slopes due to weathering. This distribution may also affect the failure mechanism as failures were concentrated in the weathered dacites from Grades III to VI (see Figure 2). Translational and discontinuity controlled failures such as plane and wedge originate in these moderately and highly weathered dacites. The translational failures are deep seated and larger. Toppling failures and columnar collapses occur in Grade II rocks. Toppling, wedge, and plane failures are restricted to a single bench. Kaolin and smectite infilled discontinuities form the rear failure planes of the translational failures and failure planes of the discontinuity controlled failures. Weathering resulting from dryingwetting cycles leads to the formation of fine debris resting 

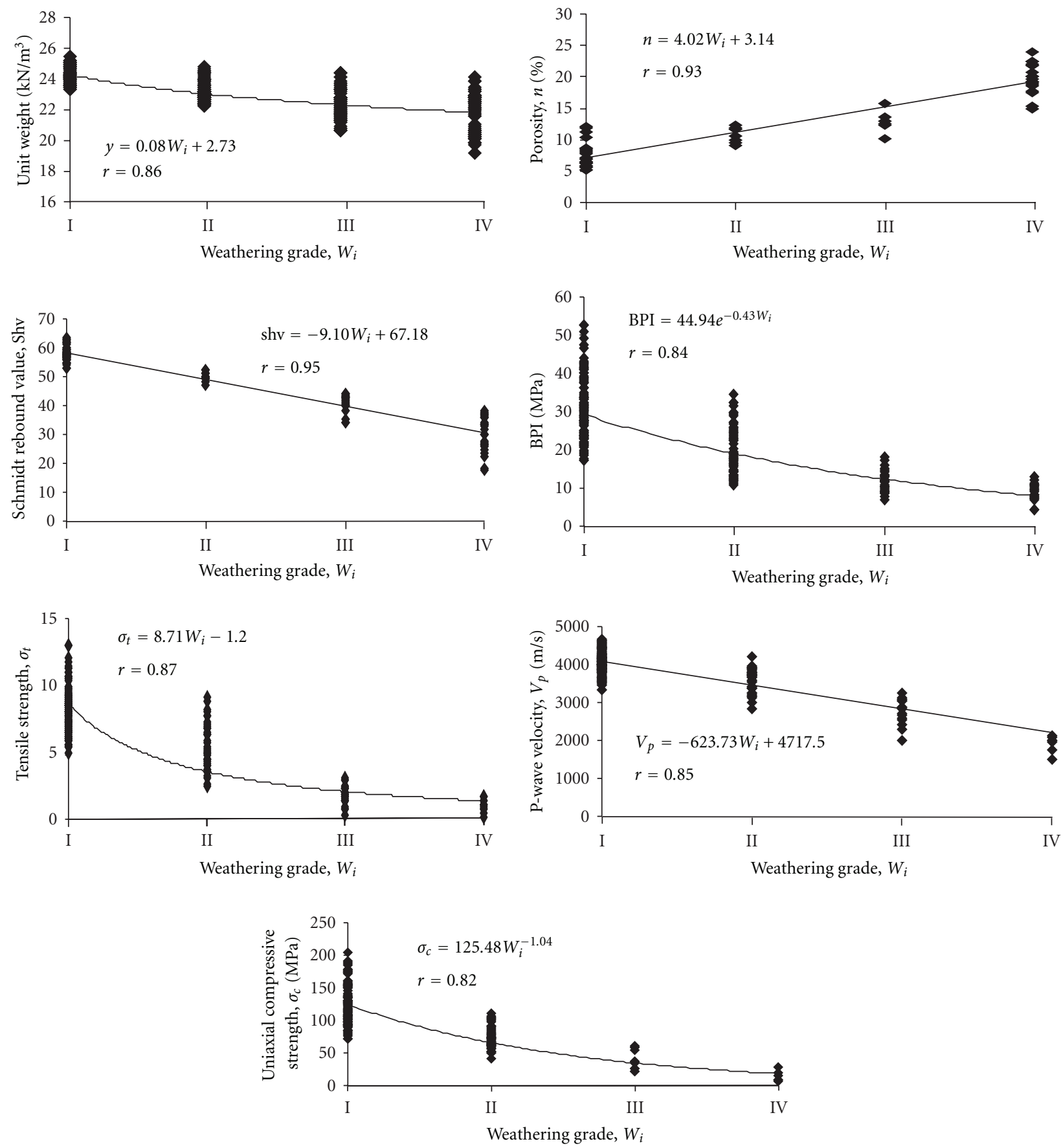

FIGURE 10: Relationship between the engineering parameters and weathering grades of the dacites.

on the foot of the slopes (Figure 12(a)), corresponding to the weathering Grade IV. On a large scale, the effects of weathering due to these cycles are observed as deteriorationrelated debris slides (Figure 12(b)) in Grade IV dacites, especially in the upper parts of the mine slopes. Frequent slope undercutting to create access roads exposes weathered dacites with corestones (Grade V), creating conditions for corestones to detach and fall. Weathering Grades V and VI are associated with soil slips with rotational mechanisms, and
Grade I rocks are not generally associated with failures in the study area.

\section{A Proposed Rock Mass Weathering Classification for the Dacites}

In order to provide accurate descriptions of the weathering stages developed in dacites, a rock mass weathering classification system for engineering purposes is proposed 


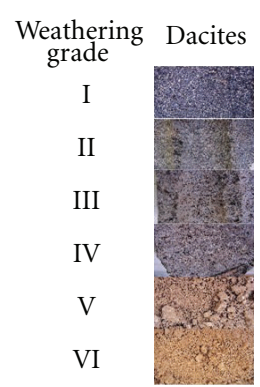

(a)

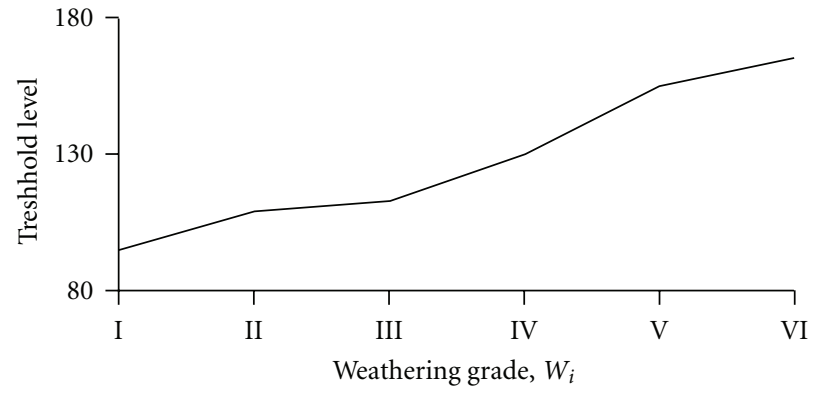

(b)

Figure 11: A view of the differently weathered dacite samples (a) and variations in their threshold levels with weathering grades (b).

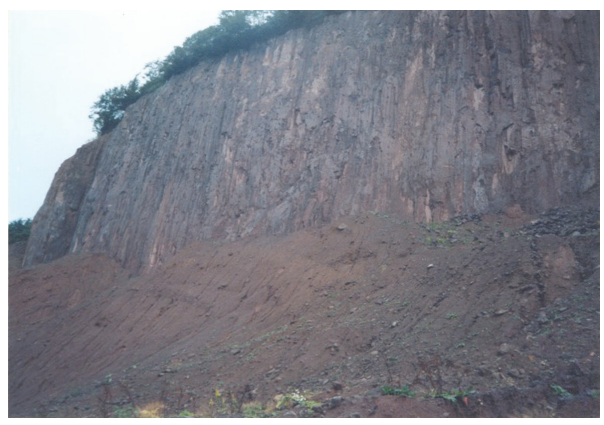

(a)

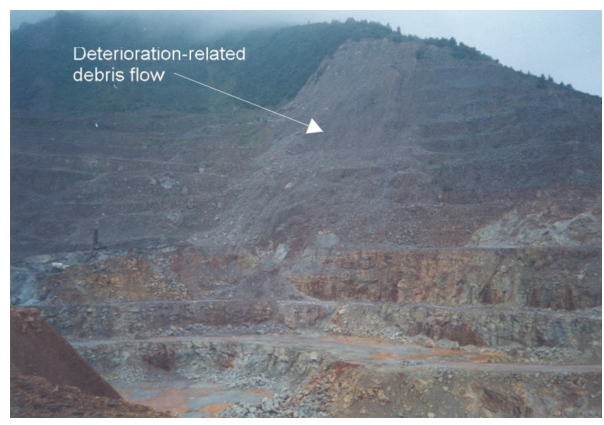

(b)

FIGURE 12: Fine debris pile at slope foot (a) and deterioration-related debris flows (b).

under the guidance of previous studies ([21-23, 29, 4349]; Table 5). The system includes six weathering grades that are defined by observations and supplemented by index tests. Mass characteristics and material features are incorporated in the descriptions. The equation obtained from the relationship between the Schmidt hammer rebound values and weathering grades (see Figure 3 ) was used to define the boundaries of the weathering grades in the proposed rock mass classification system.

\section{Conclusions}

Some conclusions can be drawn from the analyses presented in the current paper.

(1) Although chemical weathering seems to be the dominant process, fracturing and faulting are also crucial factors in the development of weathering profiles for dacites.

(2) The mineralogy and chemical composition of dacites show characteristic changes as weathering progresses. An advance in weathering from slightly to highly weathered is generally accompanied by an increase in sericite, clay, hematite, and carbonate as well as a decrease in plagioclase microlites in the dacites. In respect to clay mineralogy, the amount of clay minerals (as a product of weathering) increases significantly from Grades II to VI. The color of the samples becomes lighter with an increase in weathering due to newly formed clay minerals. Mixed-layer clay minerals, kaolinite, hematite, smectite, and vermiculite develop as the degree of weathering increases from Grade II to higher grade levels. Occurrences of these clay minerals may have been favored by impeded hydrological conditions. Generally, chemical analyses of the dacite samples show that $\mathrm{CaO}, \mathrm{MgO}, \mathrm{Na}_{2} \mathrm{O}$, and $\mathrm{K}_{2} \mathrm{O}$ decrease with weathering, while $\mathrm{Fe}_{2} \mathrm{O}_{3}$ and LOI increase with weathering. The transformation of illite and chlorite may lead to a reduction in $\mathrm{MgO}$ and $\mathrm{K}_{2} \mathrm{O}$ with increased weathering. The decomposition of feldspar may result in a loss of $\mathrm{Na}_{2} \mathrm{O}$ and $\mathrm{CaO}$ which may indicate the existence of secondary products such as clay minerals produced by chemical weathering. The LOI reflects the content of weathered minerals and may be a good indicator of chemical weathering for the dacites.

(3) The mean fracture frequencies, $q_{\mathrm{mf}}$ and RQD increase with an increase in weathering grade and these variations are particularly prominent between Grades II and III. Due to the presence of discontinuities with high $(K)$ values, which facilitate the penetration of water for further chemical weathering and hydrothermal alteration, weathering profiles in the dacites are very nonuniform. The $q_{\mathrm{mf}}$ value appears to be an appropriate measure of fabric changes from weathering for the dacites. 
TABLE 3: Major element analyses of the dacites with different weathering grades.

\begin{tabular}{|c|c|c|c|c|c|c|c|c|c|c|c|c|c|}
\hline Sample No. & Weathering Grade & $\mathrm{Na}_{2} \mathrm{O}$ & $\mathrm{MgO}$ & $\mathrm{Al}_{2} \mathrm{O}_{3}$ & $\mathrm{SiO}_{2}$ & $\mathrm{P}_{2} \mathrm{O}_{5}$ & $\mathrm{~K}_{2} \mathrm{O}$ & $\mathrm{CaO}$ & $\mathrm{TiO}_{2}$ & $\mathrm{MnO}$ & $\mathrm{Fe}_{2} \mathrm{O}_{3}$ & LOI & Total \\
\hline 21 & I & 3.50 & 2.10 & 13.5 & 67.60 & 0.10 & 3.50 & 2.70 & 0.40 & 0.10 & 5.2 & 2.50 & 101.20 \\
\hline 17 & I & 4.00 & 1.50 & 13.1 & 67.50 & 0.01 & 2.00 & 2.80 & 0.40 & 0.10 & 6.0 & 1.75 & 99.16 \\
\hline $21 \mathrm{~B}$ & I & 3.40 & 1.50 & 13.4 & 67.30 & 0.10 & 3.00 & 3.50 & 0.40 & 0.10 & 4.7 & 2.70 & 100.10 \\
\hline $12 \mathrm{~B}$ & I & 3.80 & 0.90 & 14.0 & 68.20 & 0.10 & 3.00 & 2.50 & 0.40 & 0.10 & 4.5 & 1.55 & 99.05 \\
\hline $21 \mathrm{~A}$ & I & 3.40 & 1.50 & 13.6 & 68.50 & 0.10 & 4.00 & 3.50 & 0.40 & 0.10 & 4.7 & 1.70 & 101.50 \\
\hline 12 & I & 3.80 & 0.90 & 14.0 & 69.50 & 0.10 & 4.00 & 2.50 & 0.40 & 0.10 & 4.5 & 1.55 & 101.35 \\
\hline $13 \mathrm{D}$ & I & 3.00 & 1.80 & 13.9 & 67.20 & 0.10 & 3.20 & 2.70 & 0.40 & 0.10 & 5.5 & 3.30 & 101.20 \\
\hline $10 \mathrm{~B}$ & I & 4.30 & 2.00 & 14.0 & 67.30 & 0.10 & 3.30 & 2.40 & 0.50 & 0.10 & 5.6 & 1.65 & 101.25 \\
\hline $20 \mathrm{~B}$ & II & 2.90 & 1.20 & 15.3 & 68.70 & 0.10 & 2.70 & 0.50 & 0.40 & 0.10 & 5.9 & 1.85 & 99.65 \\
\hline 20 & II & 2.90 & 1.20 & 15.3 & 70.50 & 0.10 & 3.70 & 0.50 & 0.40 & 0.10 & 2.9 & 1.85 & 99.45 \\
\hline $19 \mathrm{~A}$ & II & 4.40 & 2.10 & 13.9 & 67.20 & 0.10 & 1.30 & 2.30 & 0.40 & 0.10 & 5.7 & 1.65 & 99.15 \\
\hline $23 \mathrm{~B}$ & III & 2.60 & 1.00 & 15.0 & 69.40 & 0.10 & 2.30 & 0.20 & 0.50 & 0.10 & 6.1 & 2.25 & 99.55 \\
\hline 19 & III & 3.57 & 1.01 & 14.0 & 68.53 & 0.07 & 1.80 & 2.21 & 0.37 & 0.08 & 4.3 & 1.89 & 97.80 \\
\hline $15 \mathrm{~B}$ & III & 2.70 & 1.30 & 15.1 & 68.90 & 0.10 & 2.60 & 0.30 & 0.50 & 0.10 & 6.4 & 1.80 & 99.80 \\
\hline $20 \mathrm{~A}$ & III & 2.80 & 1.10 & 14.6 & 69.30 & 0.10 & 2.50 & 0.20 & 0.40 & 0.10 & 6.3 & 1.70 & 99.10 \\
\hline 15 & III & 2.70 & 1.30 & 15.2 & 69.60 & 0.10 & 3.70 & 0.30 & 0.50 & 0.10 & 4.4 & 1.80 & 99.70 \\
\hline $20 \mathrm{~A}$ & III & 2.80 & 1.10 & 14.6 & 70.50 & 0.10 & 3.70 & 0.20 & 0.40 & 0.10 & 4.3 & 1.70 & 99.50 \\
\hline $22 \mathrm{C}$ & III & 2.70 & 1.20 & 15.3 & 69.10 & 0.10 & 2.50 & 0.30 & 0.40 & 0.10 & 6.0 & 1.85 & 99.55 \\
\hline 23 & III & 3.30 & 1.20 & 15.1 & 68.40 & 0.10 & 2.60 & 0.40 & 0.40 & 0.10 & 6.1 & 1.55 & 99.25 \\
\hline 16 & IV & 2.40 & 1.10 & 15.2 & 69.20 & 0.10 & 2.10 & 0.20 & 0.40 & 0.10 & 6.7 & 1.85 & 99.35 \\
\hline 14 & IV & 3.25 & 0.99 & 14.3 & 69.46 & 0.10 & 2.09 & 0.43 & 0.39 & 0.07 & 4.3 & 2.12 & 99.53 \\
\hline ÇXR2 & IV & 2.80 & 1.00 & 15.3 & 68.70 & 0.10 & 2.20 & 0.20 & 0.40 & 0.10 & 6.7 & 1.70 & 99.20 \\
\hline $22 \mathrm{~B}$ & IV & 2.70 & 1.20 & 15.6 & 68.50 & 0.10 & 3.80 & 0.30 & 0.40 & 0.10 & 4.6 & 1.85 & $99 . .15$ \\
\hline ÇXR1 & IV & 2.80 & 1.00 & 15.3 & 70.10 & 0.10 & 3.60 & 0.20 & 0.40 & 0.10 & 4.7 & 1.70 & 100.90 \\
\hline $6 \mathrm{~B}$ & IV & 2.40 & 1.30 & 15.3 & 69.50 & 0.10 & 1.70 & 0.20 & 0.50 & 0.10 & 6.6 & 2.10 & 99.80 \\
\hline $22 \mathrm{~A}$ & IV & 2.40 & 1.20 & 15.6 & 68.70 & 0.10 & 2.00 & 0.20 & 0.50 & 0.10 & 6.7 & 1.90 & 99.40 \\
\hline 5 & V & 2.30 & 1.00 & 15.9 & 68.40 & 0.10 & 1.60 & 0.20 & 0.50 & 0.10 & 6.7 & 3.25 & 100.05 \\
\hline $7 \mathrm{~B}$ & $\mathrm{~V}$ & 1.00 & 0.81 & 14.8 & 67.12 & 0.03 & 1.72 & 0.57 & 0.51 & 0.09 & 5.4 & 4.22 & 97.21 \\
\hline 5 & $\mathrm{~V}$ & 2.30 & 1.20 & 15.8 & 67.70 & 0.10 & 2.60 & 0.40 & 0.50 & 0.10 & 5.6 & 3.25 & 99.55 \\
\hline $6 \mathrm{C}$ & $\mathrm{V}$ & 2.40 & 1.30 & 15.3 & 69.60 & 0.10 & 3.50 & 0.20 & 0.50 & 0.10 & 5.1 & 1.90 & 100.00 \\
\hline $22 \mathrm{C}$ & VI & 1.80 & 0.90 & 15.5 & 69.50 & 0.10 & 1.50 & 0.10 & 0.50 & 0.10 & 6.9 & 1.95 & 98.85 \\
\hline $2 \mathrm{~A}$ & VI & 0.80 & 0.90 & 15.3 & 69.80 & 0.08 & 1.75 & 0.4 & 0.50 & 0.10 & 6.1 & 2.30 & 98.03 \\
\hline $3 \mathrm{~A}$ & VI & 2.40 & 0.70 & 15.5 & 70.70 & 0.10 & 3.20 & 0.20 & 0.40 & 0.10 & 4.9 & 1.90 & 100.10 \\
\hline
\end{tabular}

(4) A good relationship between Shv and the weathering grades indicates that the Shv may be a useful tool for estimating the susceptibility of the dacites to weathering.

(5) Under the influence of weathering, a significant loss in some index and engineering properties of the dacites, such as unit weight, strength, and sonic velocity, occurred. The results also indicate an increasing trend in porosity with progressive weathering which may be due to the increase in the formation of micro cracks as well as a decrease in the initial major elemental concentrations that are mainly controlled by the decomposition of plagioclase grains. All of the investigated index and mechanical properties of the dacites in the study are closely correlated with the weathering grade. The direct use of these properties is promising for determining the extent of weathering. The grain size distribution shifts from coarse to fine from Grades V to Grade VI.

(6) Clay minerals introduced by weathering can lead to a significant reduction in the effective shear strength and stiffness of the dacite mass and may play an 
TABLE 4: Summary of statistics for the index and geomechanical parameters of the dacites in different weathering grades.

\begin{tabular}{|c|c|c|c|c|}
\hline \multirow{2}{*}{ Parameter } & \multicolumn{4}{|c|}{ Weathering grade } \\
\hline & I & II & III & IV \\
\hline Unit weight $\left(\mathrm{kN} / \mathrm{m}^{3}\right)$ & $25.3-26.9(25.9)$ & $24.4-26.1(25.5)$ & $23.8-25.0(24.4)$ & $23.3-23.8(23.5)$ \\
\hline Number of data & 156 & 51 & 19 & 10 \\
\hline P-wave velocity $(\mathrm{m} / \mathrm{s})$ & $3348.3-4680.1(4045.9)$ & $2842.9-4164.6(3628.8)$ & 2001.9-3238.7 (2775.5) & $1486.0-2142.2(1910.3)$ \\
\hline Number of data & 136 & 52 & 16 & 6 \\
\hline Tensile strength (MPa) & $5.1-13.0(8.3)$ & $3.0-9.3(5.5)$ & $1.0-4.8(2.4)$ & $0.4-2.2(1.5)$ \\
\hline Number of data & 102 & 36 & 27 & 13 \\
\hline Block punch index $(\mathrm{MPa})$ & $14.1-52.7(27.1)$ & $12.2-34.6(20.8)$ & $7.1-18.0(11.6)$ & $4.2-13.0(8.6)$ \\
\hline Number of data & 160 & 58 & 42 & 19 \\
\hline Uniaxial compressive strength (MPa) & $71.0-204.2(122.2)$ & $31.1-110.6(73.4)$ & $22.8-60.6(39.4)$ & $6.3-28.9(15.8)$ \\
\hline Number of data & 114 & 52 & 12 & 5 \\
\hline Porosity (\%) & $5.1-12.0(7.4)$ & $9.1-12.3(10.8)$ & $10.2-15.9(13.9)$ & $14.9-23.9(19.6)$ \\
\hline Number of data & 26 & 8 & 6 & 20 \\
\hline Schmidt rebound value & $52.8-63.4(58.0)$ & $47.0-52.6(50.1)$ & $34.0-52.0(42.0)$ & $17.4-38.0(30.3)$ \\
\hline Number of data & 60 & 11 & 21 & 24 \\
\hline
\end{tabular}

Note. Numbers in the parentheses indicate the mean values.

TABLE 5: Mass weathering classification system proposed for dacites in the study area.

\begin{tabular}{|c|c|}
\hline Grade & Rock mass description \\
\hline I & $\begin{array}{l}\text { No visible sign of weathering or slight discoloration on discontinuity surfaces. Rock material is very strong and highly } \\
\text { difficult to break with a hammer. Feldspar phenocrystals cannot be scratched with a nail. Contacts between } \\
\text { phenocrytals and matrix are distinct. RQD: } 50-100(\%), 54<\text { SHV } \leq 62 \text {. }\end{array}$ \\
\hline II & $\begin{array}{l}\text { Ligth and dark orange brown discoloration with no inward penetration on discontinuity surfaces. Rock material can be } \\
\text { broken with a couple of hammer blows. Edges of the specimens cannot be broken by hand. Feldspar phenocrystals } \\
\text { preserve their original shape, but they can be scratched with a nail. Toppling and columnar collapses are common. } \\
\text { RQD: } 50-100(\%), 40<\mathrm{SHV} \leq 53 \text {. }\end{array}$ \\
\hline III & $\begin{array}{l}\text { Weathering products such as clay and carbonate are observed on discontinuity surfaces. Rock is considerably weakened. } \\
\text { Discoloration partially penetrates from discontinuities. Edges of the specimens can be broken by hand. Feldspar } \\
\text { phenocrystals become gritty in appearance and can be scratched with a nail. Translational, wedge, and plane failures are } \\
\text { encountered. Rock/Soil }>50 \% \text {, RQD: } 0-50 \% \text { and } 30<\mathrm{SHV} \leq 39 \text {. }\end{array}$ \\
\hline IV & $\begin{array}{l}\text { Discontinuity surfaces are peeled and not prominent. Amount of weathering products on discontinuity surfaces } \\
\text { increases. Rock is pervasively discolored. Original texture is preserved. Feldspar phenocrystals have lost their original } \\
\text { shape. Rock material does not slake in water. Discontinuity surfaces are peeled. Translational, wedge, and plane failures } \\
\text { and debris slides are likely to occur. Rock/soil }>50 \% \text {, RQD: } 0-50 \text { and } 19<\text { SHV } \leq 29 \text {. }\end{array}$ \\
\hline $\mathrm{V}$ & $\begin{array}{l}\text { Original rock texture is present. Material slakes in water. Corestones and relict discontinuity surfaces are observed. } \\
\text { Corestones can be easily excavated with a hammer. Rocks are decomposed to soil. RQD cannot be applied and Schmidt } \\
\text { rebound values cannot be obtained. Corestone falls and circular failures are observed. }\end{array}$ \\
\hline VI & Original texture and fabric is lost. Slopes are prone to circular failures. \\
\hline
\end{tabular}

important role in the development of different types of widespread slope instability in the mines. The translational and discontinuity controlled failures such as planes and wedges developed along kaolinite and smectite-infilled discontinuity surfaces in the dacites from Grades III and IV. Columnar collapses and toppling failures occurring along these discontinuity surfaces are common in Grade II dacites. The breakdown of the rock due to the smectite content brought about by weathering leads to the formation of fine debris and contributes to the development of deterioration-related debris flow, circular failures, and corestone falls in the dacites from Grades IV to VI.

\section{Acknowledgments}

The authors would like to express their gratitude to the Mineral Research and Exploration Company of Turkey and 
the Geological Engineering Department of Hacettepe University for their permission to use the laboratories. Special thanks go to Geo engineer Serap Durmaz for thoughtful and constructive help during the study.

\section{References}

[1] H. Sverdrup and P. Warfvinge, "The role of weathering and forestry in determining the acidity of lakes in Sweden," Water, Air, and Soil Pollution, vol. 52, no. 1-2, pp. 71-78, 1990.

[2] H. Sverdrup, P. Warfvinge, and B. Nihlgard, "Assessment of soil acidification effects on forest growth in Sweden," Water, Air, and Soil Pollution, vol. 78, no. 1-2, pp. 1-36, 1994.

[3] J. C. G. Walker, P. B. Hays, and J. F. Kasting, "A negative feedback mechanism for the long-term stabilization of Earth's surface temperature.," Journal of Geophysical Research, vol. 86, no. 10, pp. 9776-9782, 1981.

[4] R. A. Berner, "A model for atmospheric $\mathrm{CO}_{2}$ over Phanerozoic time," American Journal of Science, vol. 291, no. 4, pp. 339-376, 1991.

[5] T. Y. Irfan and W. R. Dearman, "Engineering classification and index properties of a weathered granite," Bulletin of the International Association of Engineering Geology, vol. 17, no. 1, pp. 79-90, 1977.

[6] T. Y. Irfan and G. E. Powell, "Engineering geological investigations for pile foundations on a deeply weathered granitic rock in Hong Kong," Bulletin of the International Association of Engineering Geology, vol. 32, no. 1, pp. 67-80, 1985.

[7] J. Zhao, B. B. Broms, Y. Zhou, and V. Choa, "A study of the weathering of the Bukit Timah granite part A: review, field observations and geophysical survey," Bulletin of the Intenational Association of Engineering Geology, vol. 49, pp. 97106, 1994.

[8] M. D. Al-Qudami, W. M. Shehata, A. A. Al-Harthi, and A. A. Sabtan, "On the weathering of syenite under arid conditions," Bulletin of the International Association of Engineering Geology, vol. 56, pp. 3-8, 1997.

[9] S. Ceryan, K. Zorlu, C. Gokceoglu, and A. Temel, "The use of cation packing index for characterizing the weathering degree of granitic rocks," Engineering Geology, vol. 98, no. 1-2, pp. 6074, 2008.

[10] S. Y. Lee, S. J. Kim, and M. H. Baik, "Chemical weathering of granite under acid rainfall environment, Korea," Environmental Geology, vol. 55, no. 4, pp. 853-862, 2008.

[11] I. Komoo and J. Yaakub, "Engineering properties of weathered metamorphic rocks in Peninsular Malaysia," in Proceedings of the 6th International Congress (IAEG '90), pp. 665-672, Balkema, Amsterdam, The Netherlands, August 1990.

[12] L. Dobereiner, J. L. Durville, and J. Restitutito, "Weathering of the massiac gneiss (massif central, France)," Bulletin of the International Association of Engineering Geology, vol. 47, no. 1, pp. 79-96, 1993.

[13] E. A. G. Marques, E. V. Barroso, A. P. M. Filho, and E. A. Vargas Jr., "Weathering zones on metamorphic rocks from Rio de Janeiro-physical, mineralogical and geomechanical characterization," Engineering Geology, vol. 111, no. 1-4, pp. $1-18,2010$.

[14] R. K. Taylor, "Coal Measures mudrocks: composition, classification and weathering processes," Quarterly Journal of Engineering Geology, vol. 21, no. 1, pp. 85-99, 1988.

[15] A. B. Hawkins and G. M. Pinches, "Engineering description of mudrocks," Quarterly Journal of Engineering Geology, vol. 25, no. 1, pp. 17-30, 1992.
[16] M. Chigira and T. Oyama, "Mechanism and effect of chemical weathering of sedimentary rocks," Engineering Geology, vol. 55, no. 1-2, pp. 3-14, 2000.

[17] F. Bozzano, M. Gaeta, and S. Marcoccia, "Weathering of Valle Ricca stiff and jointed clay," Engineering Geology, vol. 84, no. 3-4, pp. 161-182, 2006.

[18] M. Akin and A. Özsan, "Evaluation of the long-term durability of yellow travertine using accelerated weathering tests," Bulletin of Engineering Geology and the Environment, vol. 70, no. 1, pp. 101-114, 2011.

[19] T. Saito, "Variation of physical properties of igneous rocks in weathering," in Proceedings of the International Sympossium on Weak Rocks, vol. 1, pp. 191-196, Tokyom Japan, September 1981.

[20] D. R. Haskins and F. G. Bell, "Drakensberg basalts: their alteration, breakdown and durability," Quarterly Journal of Engineering Geology, vol. 28, no. 3, pp. 287-302, 1995.

[21] C. Karpuz and A. G. Paşamehmetoğlu, "Field characterisation of weathered Ankara andesites," Engineering Geology, vol. 46, no. 1, pp. 1-17, 1997.

[22] T. Y. Irfan, "Characterization of weathered volcanic rocks in Hong Kong," Quarterly Journal of Engineering Geology and Hydrogeology, vol. 32, no. 4, pp. 317-348, 1999.

[23] V. Moon and J. Jayawardane, "Geomechanical and geochemical changes during early stages of weathering of Karamu Basalt, New Zealand," Engineering Geology, vol. 74, no. 1-2, pp. 57-72, 2004.

[24] M. Orhan, N. S. Işik, T. Topal, and M. Özer, "Effect of weathering on the geomechanical properties of andesite, Ankara-Turkey," Environmental Geology, vol. 50, no. 1, pp. 85-100, 2006.

[25] H. Stuck, L. Z. Forgo, J. Rudrich, S. Siegesmund, and A. Torok, "The behavior of consolidated volcanic tuffs: weathering mechanisms under simulated laboratory conditions," Environmental Geology, vol. 56, no. 3-4, pp. 699-713, 2008.

[26] A. M. C. Sengor, Y. Yilmaz, and I. Ketin, "Remnants of a preLate Jurassic ocean in northern Turkey: fragments of PermianTriassic Paleo-Tethys?" Bulletin of the Geological Society of America, vol. 91, no. 10, pp. 599-609, 1980.

[27] A. Dursun and H. Yilmaz, "Mining geology report of the Cakmakkaya ore body," MTA Report 9326, MTA, Ankara, Turkey, 1991.

[28] M. Z. Camur, N. Tuysuz, I. H. Guven, T. Arikal, and M. Er, "Eastern Pontides volcanism and related ore deposits," in Proceedings of the International Volcanological Congress, V. Toprak, Ed., Ankara, Turkey, September 1994.

[29] International Society for Rock Mechanics, Rock Characterization, Testing and Monitoring-ISRM Suggested Methods, Pergamon Press, Oxford, UK, 1981.

[30] R. Johnson, Elementary Statistics, Duxbury Press, Boston, Mass, USA, 1984.

[31] American Society for Testing and Materials, Soil and Rock, Annual Book of ASTM Standards: Soils and Rocks-Section 4, Construction, vol. 04.08, American Society for Testing and Materials Publication, Philadelphia, Pa, USA, 1994.

[32] G. H. Davis, Structural Geology of Rocks and Regions, John Willey \& Sons, New York, NY, USA, 1984.

[33] L'Association Francaise de Normalisation, "Essai au deu methylene," Tech. Rep. AFNOR 80181, pp. 18-592, Paris La defence, Paris, France, 1980.

[34] F. J. Baynes, W. R. Dearman, and T. Y. Irfan, "Practical assessment of grade in a weathered granite," Bulletin of the 
International Association of Engineering Geology, vol. 18, no. 1, pp. 101-109, 1978.

[35] W. R. Dearman, F. J. Baynes, and T. Y. Irfan, "Engineering grading of weathered granite," Engineering Geology, vol. 12, no. 4, pp. 345-374, 1978.

[36] A. G. Pasamehmetoglu, C. Karpuz, and T. Y. Irfan, "The weathering classification of Ankara andesites from rock mechanics point of view," in Proceedings of the International Symposium of Weak Rocks, Tokyo, Japan, Septembe 1981.

[37] F. C. Beavis, F. I. Roberts, and L. Minskaya, "Engineering aspects of weathering of low grade metapelites in an arid climatic zone," Quarterly Journal of Engineering Geology, vol. 15, no. 1, pp. 29-45, 1982.

[38] E. A. G. Marques and E. A. Vargas Jr., "Geotechnical characterization of weathering profiles in biotite gneiss (kinzigites) from Rio de Janerio city-minerological changes and physical properties," in Proceedings of the 8th International Congress (IAEG '98), pp. 2673-1680, Balkema, Vancouver, Canada, 1998.

[39] F. G. Bell and C. A. Jermy, "The geotechnical character of some South African dolerites, especially their strength and durability," Quarterly Journal of Engineering Geology, vol. 33, no. 1, pp. 59-76, 2000.

[40] K. Thuro and M. Scholz, "Deep weathering and alteration in granites-a product of coupled processes," in Proceedings of the International Conference on Coupled T-H-M-C Processes in Geosystems: Fundamentals, Modeling, Experiments and Applications (GeoProc '03), Royal Institute of Technology (KTH), October 2003.

[41] M. Akin, "A quantitative weathering classification system for yellow travertines," Environmental Earth Sciences, vol. 61, no. 1, pp. 47-61, 2010.

[42] F. Arikan, F. Yoleri, S. Sezer, D. Caglan, and B. Biliyul, "Geotechnical assessments of the stability of slopes at the Cakmakkaya and Damar open pit mines (Turkey): a case study," Environmental Earth Sciences, vol. 61, no. 4, pp. 741755, 2010.

[43] ANON, "The logging of rock cores for engineering purposes," Quarterly Journal of Engineering Geology, vol. 3, pp. 1-24, 1970.

[44] ANON, "The preparation of maps and plans in terms of engineering geology," Quarterly Journal of Engineering Geology, vol. 45, pp. 293-382, 1972.

[45] ANON, "The description of rock masses for engineering purposes," Quarterly Journal of Engineering Geology, vol. 10, pp. 355-388, 1972.

[46] D. U. Deere and F. D. Patton, "Slope stability in residual soils," in Proceedings of the 4th Pan American Conference on Soil Mechanics and Foundation Engineering, vol. 1, pp. 87-170, San Juan, Puerto Rico, October 1971.

[47] D. G. Price, "A suggested method for the classification of rock mass weathering by a ratings system," Quarterly Journal of Engineering Geology, vol. 26, no. 1, pp. 69-76, 1993.

[48] Geological Society of London, "The description and classification of weathered rocks for engineering purposes," Quarterly Journal of Engineering Geology, vol. 28, no. 3, pp. 207-242, 1995.

[49] Z. Gurocak and R. Kilic, "Effect of weathering on the geomechanical properties of the Miocene basalts in Malatya, Eastern Turkey," Bulletin of Engineering Geology and the Environment, vol. 64, no. 4, pp. 373-381, 2005. 

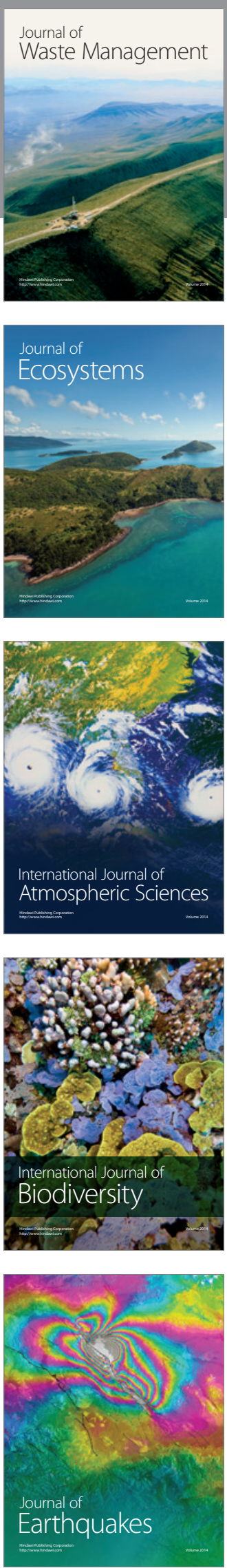
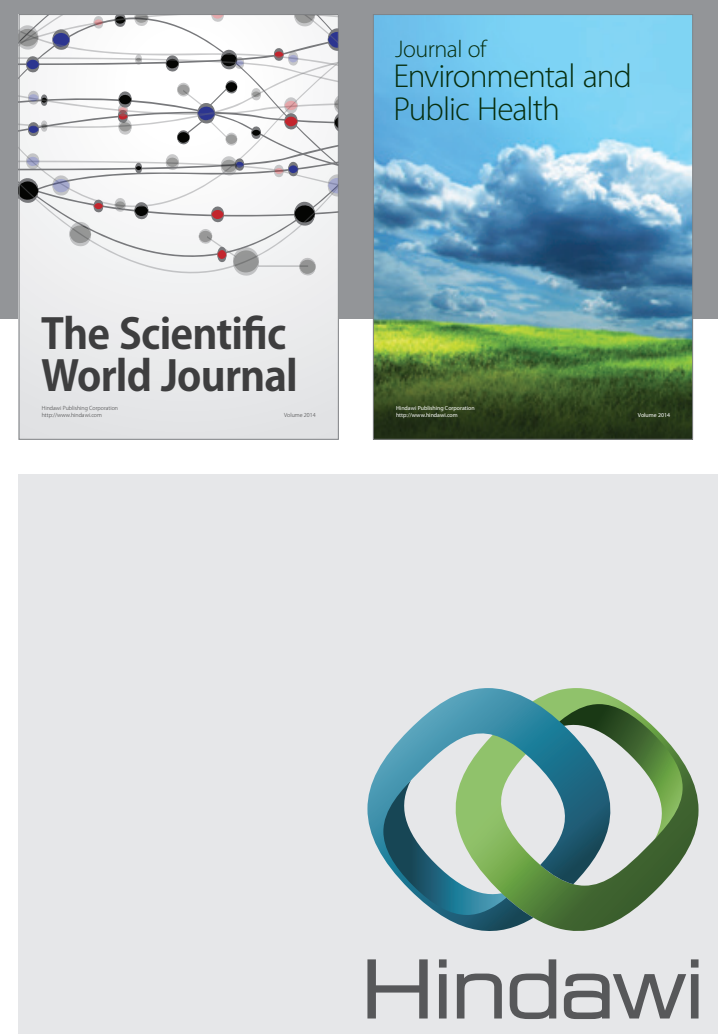

Submit your manuscripts at

http://www.hindawi.com
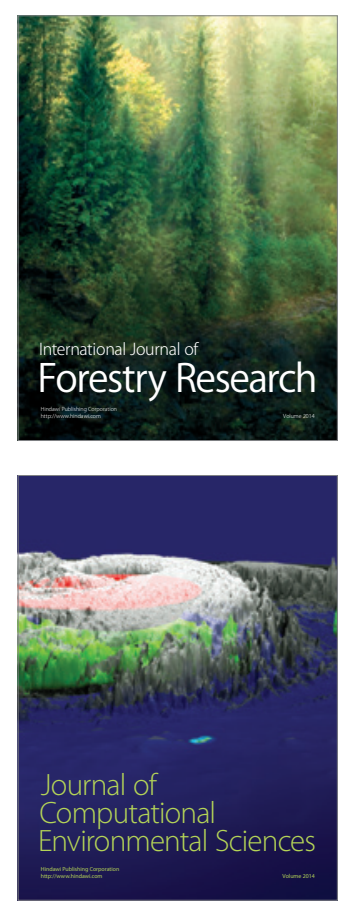
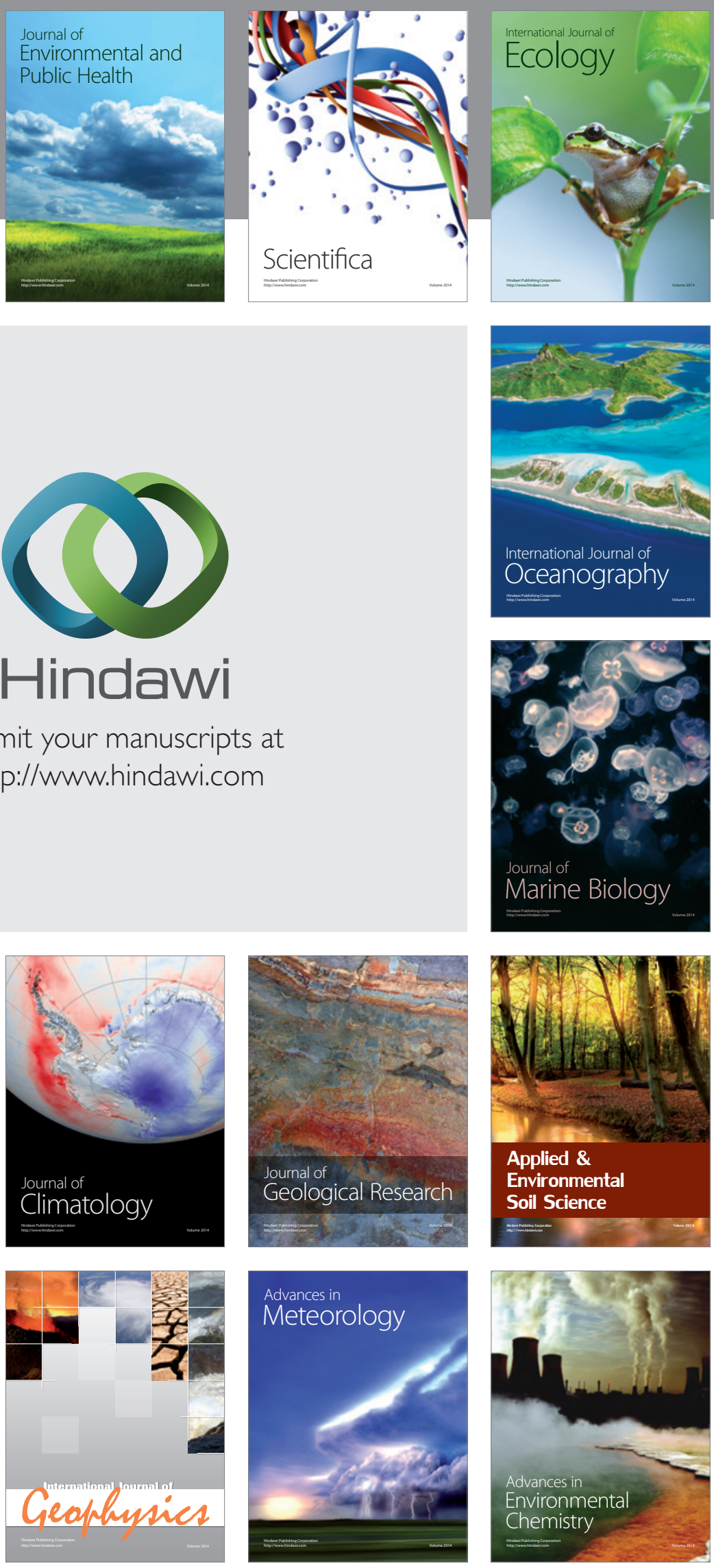